\title{
Intravitreal ranibizumab and bevacizumab therapy for choroidal neovascularization in age-related macular degeneration with extensive pre-existing geographic atrophy
}

\author{
Avaliação da resposta da injeção intravítrea de ranibizumab e bevacizumab em pacientes com \\ neovascularização de coroide da degeneração macular relacionada à idade com \\ atrofia geográfica extensa pré-existente
}

Miguel Hage Amaro ${ }^{1}$, Aaron Brock Roller ${ }^{2}$

\begin{abstract}
Purpose: To report the response of choroidal neovascularization to intravitreal ranibizumab or bevacizumab treatment in the setting of age-related macular degeneration with extensive pre-existing geographic atrophy of the retinal pigment epithelium. Methods: This is a retrospective case series of 11 eyes in ten consecutive patients retrieved from a photographic database. The patients were treated with ranibizumab or bevacizumab for neovascular age-related macular degeneration with pre-existing geographic atrophy. Patients were included if they had geographic atrophy at or adjacent to the foveal center of at least 1 disc area in size that was present before the development of choroidal neovascularization. The best corrected visual acuity and optical coherence tomography analysis of the central macular thickness were recorded for each visit. Serial injections of ranibizumab or bevacizumab were administered until there was complete resolution of subretinal fluid on optical coherence tomography. Data over the entire follow-up period were analyzed for overall visual and optical coherence tomography changes.

Results: The patients received an average of $7 \pm 3$ intravitreal injections over the treatment period. Seven of 11 eyes had reduced retinal thickening on optical coherence tomography. On average, the central macular thickness was reduced by $72 \pm 115 \mu \mathrm{m}$. Six of these 7 eyes had improvement of one or more lines of vision and one had no change. The average acuity change for all patients was $-0.04 \pm 0.46$ $\log M A R$ units, which corresponded to a gain of $0.2 \pm 4.4$ lines of Snellen acuity. The treatment resulted in a good anatomic response with resolution of the subretinal fluid and overall stable visual acuity.

Conclusions: The results of this case series suggest that the use of an intravitreal anti-vascular endothelial growth factor (VEGF) agent (ranibizumab or bevacizumab) for choroidal neovascularization in age-related macular degeneration with preexisting geographic atrophy is effective. Our results are not as striking as published results from large-scale trials of anti-vascular endothelial growth factor therapy for subfoveal choroidal neovascularization, presumably due to the limitation in the baseline visual acuity caused by the underlying geographic atrophy. The favorable anatomic response with the resolution of subretinal fluid and stable acuity were consistent with other ranibizumab and bevacizumab studies.
\end{abstract}

Keywords: Macular degeneration; Geographic atrophy; Retinal pigment epithelium, Choroidal neovascularization; Antibodies, monoclonal/therapeutic use; Retina; Antibodies, monoclonal, humanized; Tomography, optical coherence

\section{RESUMO}

Objetivo: Avaliação dos resultados da injeção intravitrea de ranibizumab e bevacizumab em pacientes com neovascularização de coróide da degeneração macular relacionada a idade, com atrofia geográfica extensa, pré-existente.

Métodos: Esteéum estudo retrospectivo de 10 pacientes, 11 ol hos com neovascularização de coroide da degeneração macular relacionada à idade, com atrofia geográfica extensa, pré-existente. Os pacientes incluídos apresentaram atrofia geográfica, envolvendo a fóvea ou adjacência, antes do desenvolvimento da neovascularização de coroide. A melhor correção visual e o exame de tomografia de coerência óptica com análise da espessura macular foram registrados em cada visita. As injeções de ranibizumab e bevacizumab intravitrea foram feitas até a resolução do líquido sub-retiniano pela tomografia de coerência óptica e clinicamente. Todos os pacientes tinham seguimento de 6 meses do diagnóstico a 2 anos, com média de 16 meses.

Resultados: Onze olhos de 10 pacientes incluídos receberam uma média de $7 \pm 3$ injeções intravitreas de ranibizumab e bevacizumab, sendo que 7 apresentaram redução do espessamento macular pelo tomografia de coerência óptica. A mácula teve o espessamento reduzido entre $72 \pm 115 \mu \mathrm{m}, 6$ olhos tiveram melhora de 1 ou mais linhas de visão, um olho teve acentuada diminuição da visão e um outro não teve alteração. A média do resultado do tratamento em logMAR era $-0,04 \pm 0,46$ correlacionando um ganho de visão na tabela de Snellen entre 0,2 $\pm 4,4$ linhas de visão.

Conclusões: Estes resultados sugerem que o uso do ranibizumab e bevacizumab intravitrea para neovascularização de coroide da degeneração macular relacionada à idade em extensa atrofia geográfica pré-existente éeficaz. Há, entretanto dificuldades na avaliação da acuidade visual destes pacientes em virtude da extensa atrofia geográfica que apresentavamesobreestaainda aneovascularização decoroide, secomparadosacasos em que a neovascularização de coroide não ocorre em atrofia geográfica pré-existente.

Descritores: Degeneração macular:Atrofia geográfica: Epitélio pigmentado da retina: Neovascularização de coroide; Anticorpos monoclonais/uso terapêutico; Retina; Anticorpos monoclonais humanizados; Tomografia de coerência óptica
Submitted for publication: November 11, 2010

Accepted for publication: June 21, 2012

Study carried out at the Retina Service, Department of Ophthalmology. University of lowa, USA.

Physician, Instituto de Olhos e Laser de Belém - Belém (PA), Brazil.

2 Physician, Department of Ophthalmology. University of lowa Hospitals and Clinics - lowa City, IA, USA.
Funding: No specific financial support was available for this study Disclosure of potential conflicts of interest: M.H.Amaro, None; A.B.Roller, None.

Correspondence address: Aaron Brock Roller. University of lowa, Department of Ophthalmology \& Visual Sciences - 200 Hawkins Drive - lowa City, lowa - USA - 52242-1091 E-mail: aaron-roller@uiowa.edu 


\section{INTRODUCTION}

Geographic atrophy (GA) of the retinal pigment epithelium is a form of advanced age-related macular degeneration (AMD) that tends to progress slowly into the center of the macula and cause vision loss. It is defined in the Age-Related Eye Disease Study (AREDS) as a well- defined patch with sharp borders, usually more or less circular shape, and depigmentation of the retinal pigment epithelium (RPE) with exposure of underlying large choroidal blood vessels $s^{(1,2)}$. GA associated with age-related macular degeneration (AMD) is estimated to affect nearly $1 \%$ of the US population, with this prevalence expected to increase by $50 \%$ by the year $2020^{(3)}$

Histopathological sections of GA show thinning or absence of the RPE, closure of the choriocapillaris, and degeneration of the overlying photoreceptors. The site of the initial appearance of GA is initially occupied by drusen, which are large (>125 $\mu \mathrm{m}$ in diameter) in $96 \%$ of cases $^{(4-6)}$. The drusen are usually confluent, with at least two in contact, and sometimes extensive enough to form plaques of drusenoid material. In addition, the GA is nearly always preceded by the appearance of hyperpigmentation around or overlying drusen, followed by regression of the drusen and the appearance of hypopigmentation, sometimes accompanied by refractile deposits. Research has shown that the strongest predictor of the subsequent spread of GA is growth in the previous 2 years ${ }^{(7,8)}$. Increased fundus autofluorescence outside atrophic patches of GA may also be an important predictor of subsequent progression ${ }^{(9)}$.

Both GA and choroidal neovascularization (CNV) are advanced forms of age-related macular degeneration ${ }^{(2,10)}$. Although pigmentary abnormalities of the RPE and drusen are precursors of neovascularization and GA, the pathophysiologic relationship between these two forms of advanced AMD is unclear. Both are commonly seen simultaneously, and the coexistence of GA and CNV has been proven histopathologically ${ }^{(4,5,11)}$.
Many studies have shown that the monoclonal antibodies to vascular endothelial growth factor (VEGF), ranibizumab and bevacizumab, improve the visual acuity in patients with AMD and subfoveal $\mathrm{CNV}^{(12-16)}$. In the MARINA and ANCHOR trials with ranibizumab, $94.6 \%$ and $96.4 \%$ of the patients avoided a 15 -letter acuity decrease, respectively. Moreover, $34 \%$ and $43 \%$ of patients gained at least 15 letters of acuity, respectively. The final mean visual acuity improved by 7.2 and 11.3 letters in the MARINA and ANCHOR trials, respectively ${ }^{(12,14)}$. Treatment of CNV with off-label use of the anti-VEGF agent bevacizumab has been shown to be equally effective ${ }^{(16)}$. The more recently introduced anti-VEGF agent aflibercept is also effective in the treatment of CNV, with comparative studies pending ${ }^{(17)}$

The utility of anti-VEGF intravitreal therapy in the treatment of CNV associated with AMD is well established. The aim of this study is to investigate the role of ranibizumab or bevacizumab intravitreal monotherapy in the treatment of CNV from AMD in eyes with extensive pre-existing GA.

\section{METHODS}

This is a retrospective case series study from a photographic database center of 11 eyes in 10 consecutive patients under active treatment with ranibizumab monotherapy for neovascular AMD in the setting of preexisting geographic atrophy. Patients were included if they had an area of GA at or adjacent to the foveal center that was at least 1 disc area in size that was present before or at the time of the development of CNV. Patients were excluded if they had any prior history of or prior treatment for CNV in the study eye. Baseline color fundus photography and fluorescein angiography was performed in all patients. The best corrected Snellen visual acuity and Heidelberg spectral-domain optical coherence tomography (OCT) were obtained at all visits.

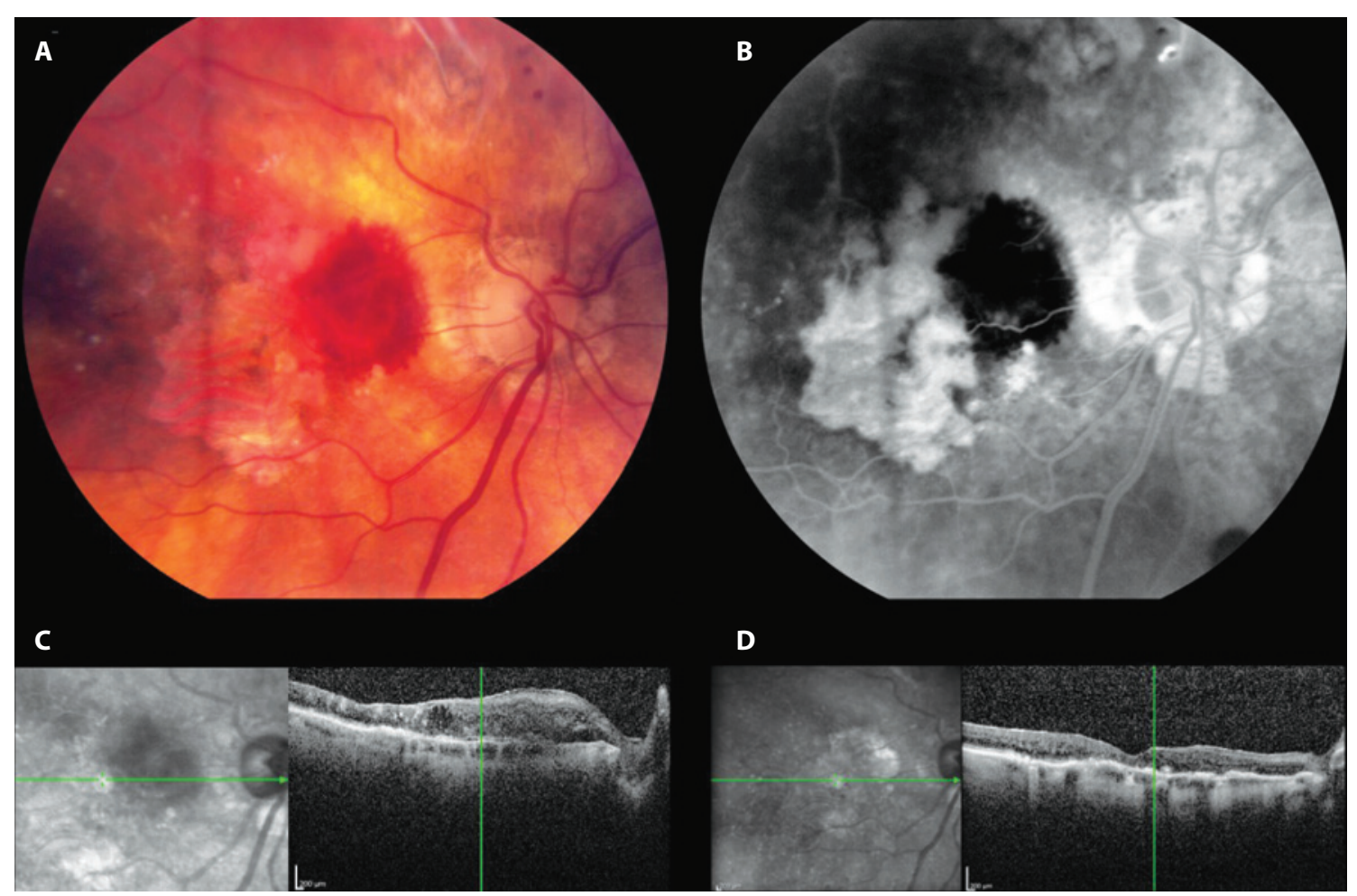

Figure 1. Fundus photographs of study eye 1 with subretinal hemorrhage resulting from occult choroidal neovascularization at the edge of pre-existing geographic atrophy (A and B), and optical coherence tomography of the central macula before (C) and two months after (D) treatment with bevacizumab, with improvement in vision from 20/100 to 20/70. 
Ranibizumab or bevacizumab were injected intravitreally every 4-6 weeks until there was resolution of the subretinal or intraretinal fluid by OCT (Figure 1), or therapy was continued in the case of persistent fluid. After resolution of fluid, a treat-and-extend approach was taken. Data on the overall visual and OCT changes over the entire available follow-up period for each patient were analyzed.

\section{RESULTS}

The study included 11 eyes from 10 patients. Four eyes were treated with ranibizumab monotherapy and seven eyes with bevacizumab monotherapy. The data for the ranibizumab and bevacizumab treated eyes were considered together for the purpose of this study given the small sample numbers. All patients were followed for at least 6 months (mean 20 months) and up to 3 years after diagnosis. The patients received an average of $7 \pm 3$ intravitreal injections over the treatment period. Seven eyes had reduced retinal thickening on OCT. On average, the central macular thickness was reduced by $72 \pm$ $115 \mu \mathrm{m}$. Six eyes had an improvement of one or more lines of Snellen acuity, three eyes lost three or fewer lines, one eye lost three lines, one eye had dramatic vision loss with hand motions due to macular hemorrhage and one eye had no change in vision (Table 1). In the eyes with mild vision loss, there was visible expansion of GA over the follow-up period. The CNV developed at the edge of the GA or in spared areas of retinal pigment epithelium within the GA in all but one eye. The average treatment outcome for all patients was $-0.04 \pm$ $0.46 \log M A R$ units, which corresponded to a gain of $0.2 \pm 4.4$ lines of Snellen acuity.

\section{DISCUSSION}

Choroidal neovascularization and GA are advanced forms of AMD as defined by the AREDS study ${ }^{(2)}$. When CNV develops in eyes with GA, it can cause both an abrupt drop in visual acuity and progression to central vision loss ${ }^{(11)}$. The AREDS data indicate that about one-third of the participants had central GA at the time when GA was first identified. There was a median time to progression from noncentral GA to central GA of 2 years. Visual acuity is often decreased before the development of central GA; for those with central GA who do not develop CNV, vision is expected to decline an additional 22 letters on average during the next 5 years. Eyes that developed subsequent CNV have an even worse prognosis(1).
CNV in eyes with GA is typically noted to develop at the edge of GA lesions or in new areas previously uninvolved by GA. In a case report on a patient with GA with histopathological correlation in whom the existence of CNV was not initially suspected and a fluorescein angiogram had not revealed CNV, the researchers noted that CNV developed in one eye with GA in areas of residual choriocapillaris and pigment epithelium, while no CNV developed in the fellow eye with GA despite breaks in Bruch's membrane. This was presumably because the breaks occurred in areas of GA, without residual choriocapillaris and RPE(5). This finding is similar to the recent study by Sunness et al, in which no CNV was noted to develop within areas of $\mathrm{GA}^{(11)}$. Our case series also mirrors this finding (Figure 1).

The MARINA and ANCHOR studies proved the efficacy of antiVEGF therapy with ranibizumab in the treatment of subfoveal CNV ${ }^{(12,14)}$. The CATT study confirmed these results and demonstrated the equivalent efficacy of ranibizumab and bevacizumab ${ }^{(16)}$. In our study of ranibizumab or bevacizumab treatment for CNV in AMD with pre-existing GA, 63\% of eyes had improvement of one or more lines of vision, with an average gain of 0.2 lines. In comparison to the Macular Photocoagulation Study, with only 57\% of patients with extrafoveal CNV and $26 \%$ of patients with juxtafoveal CNV demonstrating stable or improved vision, our patients had improved outcomes as well ${ }^{(18-20)}$. Given that our patients tended to have poorer vision and central vision loss at baseline due to pre-existing atrophy, our results compare favorably to the other ranibizumab and bevacizumab studies, with disappearance of the subretinal fluid and overall stable visual acuity. Therefore GA, of itself, should not be a contraindication to anti-VEGF treatment for eyes with CNV.

\section{CONCLUSION}

This small case series demonstrates that the use of the intravitreal anti-VEGF agents ranibizumab and bevacizumab for CNV in AMD with significant preexisting GA was largely effective for the patients in our series. Our results are not as striking as the results of large-scale trials of anti-VEGF therapy for subfoveal CNV, presumably due to the limitation of improvement of visual acuity over baseline caused by the underlying GA. Our study is limited by a very small sample size, and a larger prospective study with longer follow-up is needed to confirm our results.

\begin{tabular}{|c|c|c|c|c|c|c|c|}
\hline Eye & Agent & $\begin{array}{c}\text { Initial acuity } \\
\text { (Snellen) }\end{array}$ & $\begin{array}{c}\text { Number of } \\
\text { injections }\end{array}$ & $\begin{array}{l}\text { Follow-up } \\
\text { (months) }\end{array}$ & $\begin{array}{l}\text { Final acuity } \\
\text { (Snellen) }\end{array}$ & $\begin{array}{l}\text { Total change in } \\
\text { (acuity lines) }\end{array}$ & $\begin{array}{c}\text { Change in OCT } \\
\text { from baseline }(\mu \mathrm{m})\end{array}$ \\
\hline 1 & Bevacizumab & $20 / 100$ & 3 & 6 & 20/70 & +2 & -167 \\
\hline 2 & Bevacizumab & $20 / 160$ & 6 & 24 & $20 / 200$ & -1 & -215 \\
\hline 3 & Ranibizumab & $20 / 40$ & 10 & 30 & $20 / 300$ & -9 & -50 \\
\hline 4 & Ranibizumab & $20 / 250$ & 5 & 24 & $20 / 70$ & +6 & -91 \\
\hline 5 & Bevacizumab & $20 / 60$ & 3 & 16 & 20/100 & -3 & 15 \\
\hline 6 & Bevacizumab & $20 / 125$ & 3 & 16 & $20 / 80$ & +2 & -201 \\
\hline 7 & Ranibizumab & $20 / 40$ & 11 & 30 & $20 / 40$ & 0 & 52 \\
\hline 8 & Bevacizumab & $20 / 400$ & 10 & 12 & $20 / 50$ & +7 & -227 \\
\hline 9 & Bevacizumab & $20 / 600$ & 6 & 8 & $20 / 800$ & -1 & 12 \\
\hline 10 & Bevacizumab & $20 / 50$ & 12 & 21 & $20 / 70$ & -2 & -16 \\
\hline \multirow[t]{2}{*}{11} & Ranibizumab & $20 / 60$ & 5 & 36 & $20 / 50$ & +1 & 93 \\
\hline & Average: & & $7 \pm 3$ & $20 \pm 10$ & & $+0.2 \pm 4.4$ & $-72 \pm 115$ \\
\hline
\end{tabular}




\section{ACKNOWLEDGEMENTS}

We thank Dr. James C. Folk, the Judith (Gardner) and Donald H. Beisner, M.D. Professor of Vitreoretinal Diseases and Surgery at the University of lowa, lowa City, lowa USA for his generous help with the design and completion of this study.

\section{REFERENCES}

1. Lindblad AS, Lloyd PC, Clemons TE, eGensler GR, Ferris FL $3^{\text {rd }}$, Klein ML, Armstrong JR; Age-Related Eye Disease Study Research Group. Change in area of geographic atrophy in the Age-Related Eye Disease Study: AREDS report number 26. Arch Ophthalmol. 2009:127(9):1168-74

2. Age-Related Eye Disease Study Research Group. A randomized, placebo-controlled, clinical trial of high-dose supplementation with vitamins $C$ and $E$, beta carotene, and zinc for age-related macular degeneration and vision loss: AREDS report no. 8. Arch Ophthalmol. 2001;119(10):1417-36. Erratum in: Arch Ophthalmol. 2008;126(9): 1251.

3. Friedman DS, O'Colmain BJ, Muñoz B, Tomany SC, McCarty C, de Jong PT, Nemesure B, Mitchell P, Kempen J; Eye Diseases Prevalence Research Group. Prevalence of age-related macular degeneration in the United States. Arch Ophthalmol. 2004; 122(4):564-72. Comment in: JAMA. 2004;291(15):1900-1.

4. Green WR, Enger C. Age-related macular degeneration histopathologic studies. The 1992 Lorenz E. Zimmerman Lecture. Ophthalmology. 1993;100(10):1519-35.

5. Green WR, Key SN $3^{\text {rd }}$. Senile macular degeneration: a histopathologic study. Trans Am Ophthalmol Soc. 1977;75:180-254.

6. Klein ML, Ferris FL $3^{\text {rd }}$, Armstrong J, Hwang TS, Chew EY, Bressler SB, Chandra SR; AREDS Research Group. Retinal precursors and the development of geographic atrophy in age-related macular degeneration. Ophthalmology. 2008;115(6):1026-31.

7. Sunness JS, Margalit E, Srikumaran D, Applegate CA, Tian Y, Perry D, et al. The longterm natural history of geographic atrophy from age-related macular degeneration: enlargement of atrophy and implications for interventional clinical trials. Ophthalmology. 2007;114(2):271-7

8. Sunness JS, Applegate CA, Bressler NM, Hawkins BS. Designing clinical trials for agerelated geographic atrophy of the macula: enrollment data from the geographic atrophy natural history study. Retina. 2007;27(2):204-10.

9. HolzFG, Bindewald-Wittich A, Fleckenstein M, Dreyhaupt J,Scholl HP, Schmitz-Valckenberg S. Progression of geographic atrophy and impact of fundus autofluorescence patterns in age-related macular degeneration. Am J Ophthalmol. 2007;143(3): 463-72.
10. Gass JD. Drusen and disciform macular detachment and degeneration. Trans Am Ophthalmol Soc. 1972;70:409-36.

11. Sunness JS, Gonzalez-Baron J, Bressler NM, Hawkins B, Applegate CA. The development of choroidal neovascularization in eyes with the geographic atrophy form of age-related macular degeneration. Ophthalmology. 1999;106(5):910-9.

12. Rosenfeld PJ, Brown DM, Heier JS, Boyer DS, Kaiser PK, Chung CY, Kim RY: MARINA Study Group. Ranibizumab for neovascular age-related macular degeneration. N Engl J Med. 2006;355(14):1419-31. Comment in: N Engl J Med. 2006;355(14):1409-12. N Engl J Med. 2007:356(7):748-9; N Engl J Med. 2006;355(14):1493-5.

13. Rich RM, Rosenfeld PJ, Puliafito CA, Dubovy SR, Davis JL, Flynn HW Jr, et al. Short-term safety and efficacy of intravitreal bevacizumab (Avastin) for neovascular age-related macular degeneration. Retina. 2006;26(5):495-511.

14. Brown DM, Kaiser PK, Michels M, Soubrane G, Heier JS, Kim RY, SY JP, Schneider S; ANCHOR Study Group. Ranibizumab versus verteporfin for neovascular age-related macular degeneration. N Engl J Med. 2006;355(14):1432-44. Comment in: N Engl J Med. 2006;355(14):1409-12; N Engl J Med. 2007;356(7):748-9; N Engl J Med. 2007;356(7):747-8; N Engl J Med. 2006;355(14):1493-5.

15. Rosenfeld PJ, Moshfeghi AA, Puliafito CA. Optical coherence tomography findings after an intravitreal injection of bevacizumab (Avastin) for neovascular age-related macular degeneration. Ophthalmic Surg Lasers Imaging. 2005;36(4):331-5. Comment in: Ophthalmic Surg Lasers Imaging. 2005;36(4):270-1.

16. CATT Research Gourp, Martin DF, Maguire MG, Ying GS, Grunwald JE, Fine SL, Jaffe GJ. Ranibizumab and bevacizumab for neovascular age-related macular degeneration. N Engl J Med. 19;364(20):1897-908. Comment in: N Engl J Med. 2011;365(23):2237; N Engl J Med. 2011;365(23):2238; Clin Experiment Ophthalmol. 2011;39(7):718-20; N Engl J Med. 2011;364(20):1966-7.

17. Dixon JA, Oliver SC, Olson JL, Mandava N. VEGF Trap-Eye for the treatment of neovascular age-related macular degeneration. Expert Opin Investig Drugs. 2009; 18(10):1573-80

18. Laser photocoagulation for juxtafoveal choroidal neovascularization. Five-year results from randomized clinical trials. Macular Photocoagulation Study Group. Arch Ophthalmol. 1994;112(4):500-9.

19. Five-year follow-up of fellow eyes of patients with age-related macular degeneration and unilateral extrafoveal choroidal neovascularization. Macular Photocoagulation Study Group. Arch Ophthalmol. 1993;111(9):1189-99. Comment in: Arch Ophthalmol. 1994;112(7):874-5

20. Krypton laser photocoagulation for neovascular lesions of age-related macular degeneration. Results of a randomized clinical trial. Macular Photocoagulation Study Group. Arch Ophthalmol. 1990;108(6):816-24. Comment in: Arch Ophthalmol. 1991;109(5):614-5.

\title{
V Jornada de Oftalmologia do Hospital São Rafael
}

\section{1 e 2 de março de 2013}

\author{
Hospital São Rafael
}

Salvador (BA)

\section{Informações:}

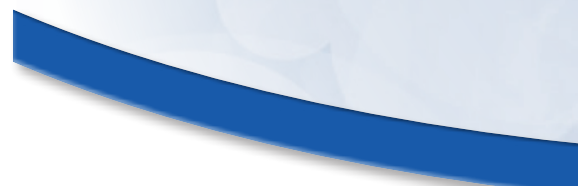

E-mail: dimagnavitaeventos@yahoo.com.br

Site: www.ceosr.com.br/jornada 